\title{
Accounting Interpretation of Cross- border Mergers in the Czech Republic Based on Czech Accounting Standards
}

\author{
Jana SKÁLOVÁ* - Tomáš PODŠKUBKA ${ }^{* *}$
}

\section{Legal regulation}

The Czech Republic as all other EU member states was bound to implement the Directive 2005/56/EC of 26 October 2005 on cross-border mergers of limited liability companies ${ }^{1}$ (Eur-Lex, 2005a) to the Czech legal system in 2007. This directive was made public in the Official Journal of the EU on 25 November 2005. The member states were obliged to transpose this Directive to their laws and regulations by 15 December 2007.

Additional to the Tenth Directive, the European Court of Justice issued a judgement in the legal case No. C-411/03 SEVIC Systems AG of 13 December 2005 (Eur-Lex, 2005b). This judgment belongs among key court decisions in terms of freedom of establishment application and interpretations of Articles No. 43 and 48 of the Treaty establishing the European Community. According to this ruling, a member state shall not withhold powers of limited liability companies which arise from freedom of establishment. This statement is based on the superiority of acquis communautaire.

The Act No. 125/2008 Coll., on transformations of businesses and cooperatives $^{2}$ (Portal Gov, 2008a) came into legal force on 1 July 2008.

Ing. Jana Skálová - partner; TPA Horwath Notia Tax s.r.o., Mánesova 917/28, 12000 Prague 2 Czech Republic - Ph.D. student; Department of Financial Accounting and Auditing, Faculty of Finance and Accounting, University of Economics, Prague, Czech Republic; <jana.skalova@vse.cz>.

** Ing. Tomáš Podškubka - manager of TPA Horwath Valuation Services s.r.o., Mánesova 917/28, 12000 Prague 2, Czech Republic - Ph.D. student; Department of Corporate Finance and Valuation, Faculty of Finance and Accounting, University of Economics, Prague, Czech Republic; <tomas.podskubka@vse.cz>.

1 Sometimes referred to as "Tenth Directive".

2 Hereinafter referred to as "Business Transformations Act or BTA". 
This fact means that the Czech Republic has met its duties to transpose the above mentioned Directive to the legal system. It can be thus stated that from 1 July 2008 onwards, cross-border mergers of common businesses can be carried out from the legal perspective. Together with the BTA, the accompanying Act No. 126/2008 Coll. (Portal Gov, 2008b) amending related regulations; e.g. Accounting Act, Income Tax Act and Provisions Act; was approved and ratified.

A comprehensive accounting related legal regulation had not been introduced until the amendment of the public notice No. 500/2002 Coll. on accounting of businesses (Portal Gov, 2002) and the amendment of Czech Accounting Standard No. 011 on transactions with businesses (MFČR, 2009).

The accounting obligations of businesses participating in cross-border mergers in the Czech Republic and related income tax issues are described in the following paper.

\section{Draft Terms of Cross-border Mergers}

\subsection{Decisive day}

The basic legal document, based on which cross-border mergers are executed, is the merger project. ${ }^{3}$ The actual terms that each project shall include are stipulated by the Directive.

The decisive day and its determination is a fundamental starting point for accounting obligations of all participating companies (this concept is unified by the Directive within the EU).

The decisive day is a date from which the transactions of the merging companies will be treated for accounting purposes as being those of the company resulting from the merger (i.e. the successor company). In other words, all accounting entries concerning assets, liabilities, equity, revenues and expenses of the merging companies recorded after the decisive day belong to the successor company and its financial statements. This accounting concept deviates from the legal concept of

3 The Directive uses the term "draft terms" instead of the term merger project that will be used in this article hereinafter. 
the merging companies' legal existence, which ceases with the registration of the merger in the Commercial Register.

This definition is followed up by Act No. 563/1991 Coll., on accounting, as amended ${ }^{4}$ (Portal Gov, 1991), which lays down the rules for accounting period determination and for the opening and closing of accounting books during mergers.

As a consequence of this Czech regulation, the decisive day triggers the following obligations:

1. to prepare the final financial statements of all participating companies as of the day preceding the decisive day,

2. to prepare valuation reports on the value of the net assets of all the merging companies as of the day preceding the decisive day if revaluation is also required explicitly by the BTA,

3. to prepare an opening balance sheet of the successor company as of the decisive day.

The accounting period of all participating companies (i.e. all merging companies and also the successor company) terminates on the day preceding the decisive day according to the BTA. The new accounting period of the successor company starts on the decisive day and terminates on the last day of the standard accounting period, in which the merger is registered in the Commercial Register.

The decisive day is usually set retrospectively and must not predate the day on which a court petition for the merger registration in the Commercial Register is filed by more than 12 months.

The merging companies cannot, however, cease to keep accounts after the decisive day. The participating companies must conduct accounting procedures separately from the decisive day until the registration of the merger has been entered in the Commercial Register. These procedures may be necessary in case the merger has been either refused to be registered in the Commercial Register by the court or disapproved at the companies' general meetings. In such cases, the companies are obliged to fulfil their duties in the area of accounting and ensure that accounting entries are made on a regular basis as if the merger had never been planned.

4 Hereinafter referred to as "Accounting Act". 
The successor company shall combine its accounts with the merging companies' accounts as of the date of registration of the merger in the Commercial Register with effects from the decisive day. For this purpose, the opening balance sheet is prepared as the first document of the combined accounting. As of this date, accounting records will be combined in reality and concurrently all mutual business transactions (e.g. mutual payables, receivables, revenues and expenses) which occurred in the period between the decisive day and the date of registration in the Commercial Register will be excluded (for more details see also Skálová - Čouková, 2008).

\subsection{Financial statements during cross-border mergers}

The requirement to determine a date of the merging companies' financial statements used to establish the conditions of the cross-border merger is included in other vital terms of the merger project. These financial statements may, for instance, be used to calculate share exchange ratios for participating shareholders. This day may be set no earlier than on the day preceding the decisive day of the merger, as of which final financial statements and valuation reports on the net assets value of merging companies are prepared.

Nonetheless, this day may be set at a later date following the decisive day of the merger.

The Tenth Directive and the Czech BTA lay down the obligation to prepare interim financial statements provided the day of the merger project preparation occurs 6 months later than the final financial statements are prepared.

It is worth mentioning that the period between the decisive day of the merger and the day as of which the petition for merger registration to the Commercial Register has been filed, has been extended in the Czech Republic from 9 to 12 months with the brand new BTA effective since 1 July 2008. This change will certainly increase the importance of interim financial statements prepared at mergers. Besides that, the BTA comprises another time limit for the interim financial statements. These financial statements may not be prepared earlier than 3 months before the date of the cross-border merger project preparation. 


\subsection{Information on valuation of assets and liabilities transferred to the successor company}

The merger project must also include information on the valuation of the assets and liabilities which are transferred to the company resulting from the cross-border merger.

According to the Czech Accounting Standards, the successor company is allowed to take over the assets and liabilities of the merging companies in:

- market values determined in expert valuation reports (in accounting terminology: in fair values),

- accounting prices (historical or acquisition prices).

Czech commercial law strictly applies the institute of the EU law that all in-kind contributions in registered capital of limited liability companies shall be valued by an expert appointed by court.

In a merger of capital companies (private or public) and under the condition that by virtue of the merger (i) the registered capital of the successor company shall be increased via new share issues or contributions and (ii) the source of the increase is the equity of the merging companies, the net assets of the merging companies have to be valued by an expert appointed by court. In principle, shareholders of the merging companies will obtain contributions (share) in the registered capital of the successor company.

On the other hand, in a merger (regardless of whether upstream or downstream) of a $100 \%$ mother and daughter company or in a merger of sister companies with identical owners and provided the registered capital is not increased from equity of the merging companies, no expert valuation has to be made. In such cases, assets, liabilities and equity of the merging companies are taken over in accounting prices. 
Fig. 1: Types of mergers without expert valuation

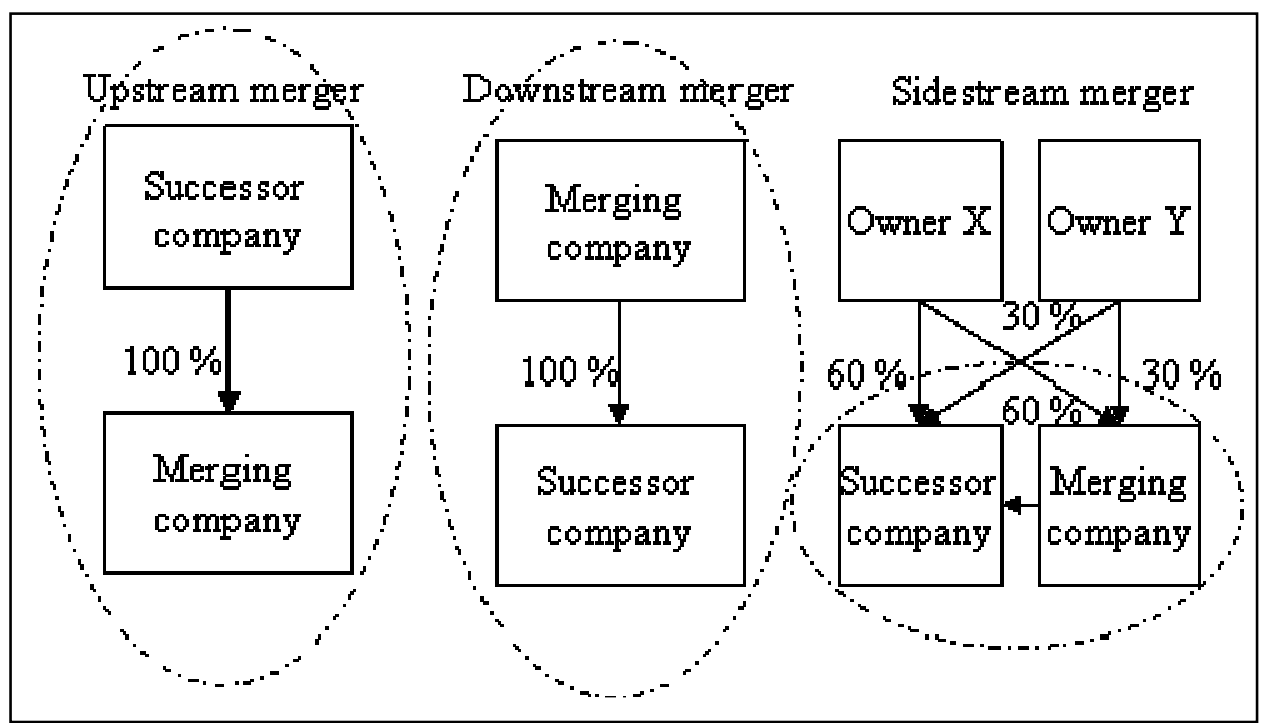

Information on valuation of the assets and liabilities which are transferred to the successor company, which must be mentioned in the merger project, thus advises the shareholders of the net assets crossborder transfer realised between the countries of the participating companies' domiciles. It should be noted that in some cases this transfer is purely virtual (e.g. real estate transfers).

If the successor company is seated in the Czech Republic, valuation of acquired assets and liabilities from abroad must be adapted to meet the Czech Accounting Standards and the structure of equity must be adapted to conform to the Czech commercial law code.

At the participating companies' general meetings, the merger project should be approved. This is, however, not the only document to be approved. From the accounting point of view, final financial statements of all participating companies and the opening balance sheet of the successor company are also on the list. Generally speaking, final financial statements are prepared according to national accounting or other regulations of the states in which the participating companies are seated. The opening balance sheet then includes compound information disclosed according to the regulation applied in the successor company's domicile. This is probably the reason why the legislatures came to the conclusion that it may be worthwhile to supplement the merger project with 
mandatory information on the valuation of the assets and liabilities which are transferred to the successor company. This obligation laid down in the Czech BTA comes directly from the Directive, which unfortunately does not include any further clarification to this term of the project.

Focusing on the case that the successor company is seated in the Czech Republic, the valuation of the assets and liabilities listed in the merger project should inform the shareholders of how the accounts of the foreign final financial statements prepared according to foreign accounting standards and legal regulation were entered in the opening balance sheet of the successor company prepared in compliance with the Czech Accounting Standards and Czech legal regulation.

\section{Options of Cross-border Mergers}

\subsection{Cross-border merger into the Czech Republic}

The Czech Accounting Standards are now prepared for taking over accounts of foreign legal entities during a cross-border merger with merging companies abroad and a successor company in the Czech Republic. In practice, we can only come across two possibilities. The first one assumes that the business activity of the merging company, which was dissolved in the merger, can remain abroad and become a part of a foreign permanent establishment owned by the Czech successor company. This permanent establishment will be considered as a dislocated division and will be treated as such in bookkeeping of the Czech successor company. The second one, on the other hand, is based on the factual moving of assets and liabilities constituting business activities of the foreign merging companies to the Czech Republic. In this case, the real physical merger of assets and liabilities will occur in the Czech Republic.

Accordingly, both possibilities involve having to deal with valuation of the assets and liabilities acquired in the merger at the first stage. 
Fig. 2: Cross-border merger into the Czech Republic

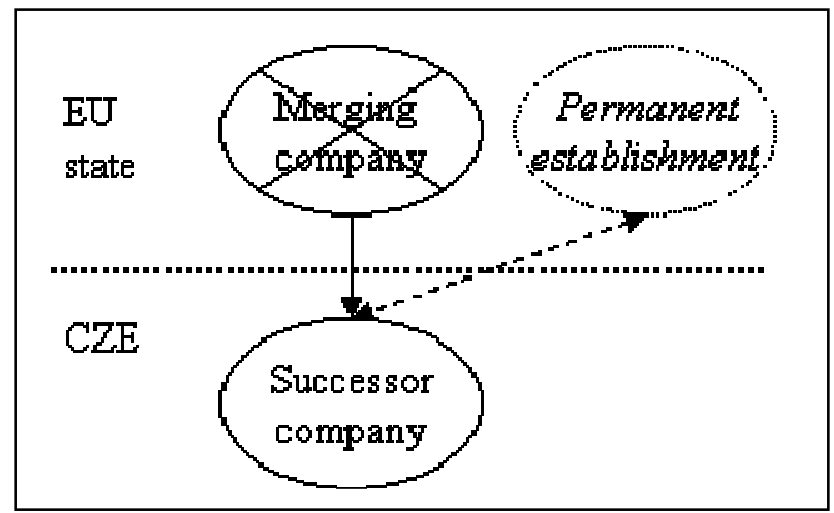

\subsection{Cross-border merger out of the Czech Republic}

If a Czech merging company is dissolved in a cross-border merger with a foreign legal successor, two analogous possibilities can take place. The first one is based on the real physical transfer of assets and liabilities abroad and causes the Czech merging company to cease to be an accounting unit according to the Czech Accounting Standards. The second alternative, by contrast, involves founding a permanent establishment of the successor company in the Czech Republic since the business activity remains in the Czech Republic. This entity shall be registered in the Czech Commercial Register as a dislocated division of the foreign company and considered to be an accounting unit pursuant to the Czech Accounting Act. For tax purposes, the term permanent establishment is chiefly used for such an entity.

As a result of being an accounting unit, the permanent establishment is subject to all duties stipulated by the Accounting Act in the same manner as other Czech accounting units. The requirement to comply with all provisions of the Accounting Act may bring about great difficulties, whose satisfactory solution may be a challenge.

In any case, many practitioners and academics (e.g. Roubíčková, 2008) in the Czech Republic hold the view that the relevant provisions of the Accounting Act that impose this duty on permanent establishments seated in the Czech Republic should be abolished. Consequently, permanent establishments will be relived of some duties and will therefore not have to deal with all requirements laid down by the 
Accounting Act. On the other hand, they would have to be instructed in a legally binding manner to keep records in order to determine the income tax base from transactions taxable in the Czech Republic. This solution will resemble the procedure used by companies reporting under IAS/IFRS, which are obliged to follow accounting instructions ${ }^{5}$ that lead to the determination of accounting profit/loss for the purposes of the tax base calculation.

Fig. 3: Cross-border merger out of the Czech Republic

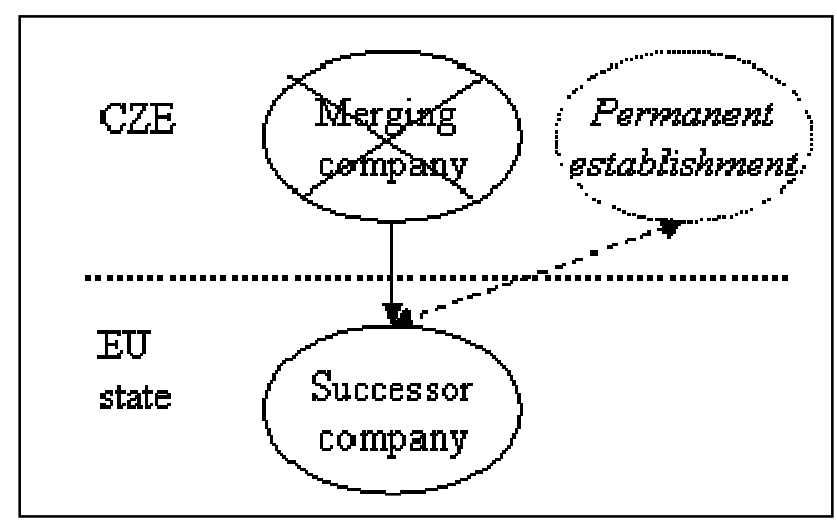

\section{Accounting Duties at Cross-border Mergers into the Czech Republic}

\subsection{Opening balance sheet}

The very first moment, when the assets and liabilities of foreign merging companies must be recorded in the accounting of a Czech successor company is the decisive day of merger, as of which an opening balance sheet must be prepared. The opening balance sheet includes the assets and liabilities of all participating companies, which are valued in accordance with the Czech Accounting Standards.

The decisive day is therefore a moment of "accounting" acquisition of all assets and liabilities, although it is a legal fiction.

5 Directive No. D-295 of the Czech Ministry of Finance 


\subsection{Disclosure of assets, liabilities and equity according to Czech Accounting Standards}

As of the decisive day, a Czech successor company must value all assets and liabilities obtained from merging companies in compliance with the Accounting Act.

The actual procedure implemented in accounting books of the Czech successor company may be also affected by the merger type that is feasible under the BTA (i.e. upstream, downstream or sidestream mergers). Provided an upstream, or with inconsequential restrictions a downstream, merger with an increase of registered capital of the Czech successor company from equity of the merging companies is carried out, net assets of the merging companies shall be valued by an expert appointed for this purpose by the court. Likewise, an expert valuation must be prepared and booked if a sidestream merger is realised. Cases where no expert valuation is needed have already been mentioned earlier in this paper. In such mergers, accounting values are taken over to the successor company.

The Czech Accounting Standards concerning common businesses include an obligatory layout of assets, equity and liabilities in a balance sheet. Merger-related items in equity are shown in bold in the following table.

Tab. 1: Merger related items of equity in a balance sheet

\begin{tabular}{|l|l|}
\hline Code & \multicolumn{1}{|c|}{ Title } \\
\hline A.II & Capital Funds \\
\hline A.II.1 & Share Premium \\
\hline A.II.2 & Other Capital Funds \\
\hline A.II.3 & Valuation Difference from Revaluation of Assets and Liabilities \\
\hline A.II.4 & Valuation Difference from Revaluation at Transformations \\
\hline A.II.5 & Differences from Transformations \\
\hline
\end{tabular}

Source : Portal Gov (2002) 


\subsection{Process of an opening balance sheet preparation}

The actual process is not dependent on the final financial statements of the merging company seated abroad.

Fig. 4: Process of an opening balance sheet preparation

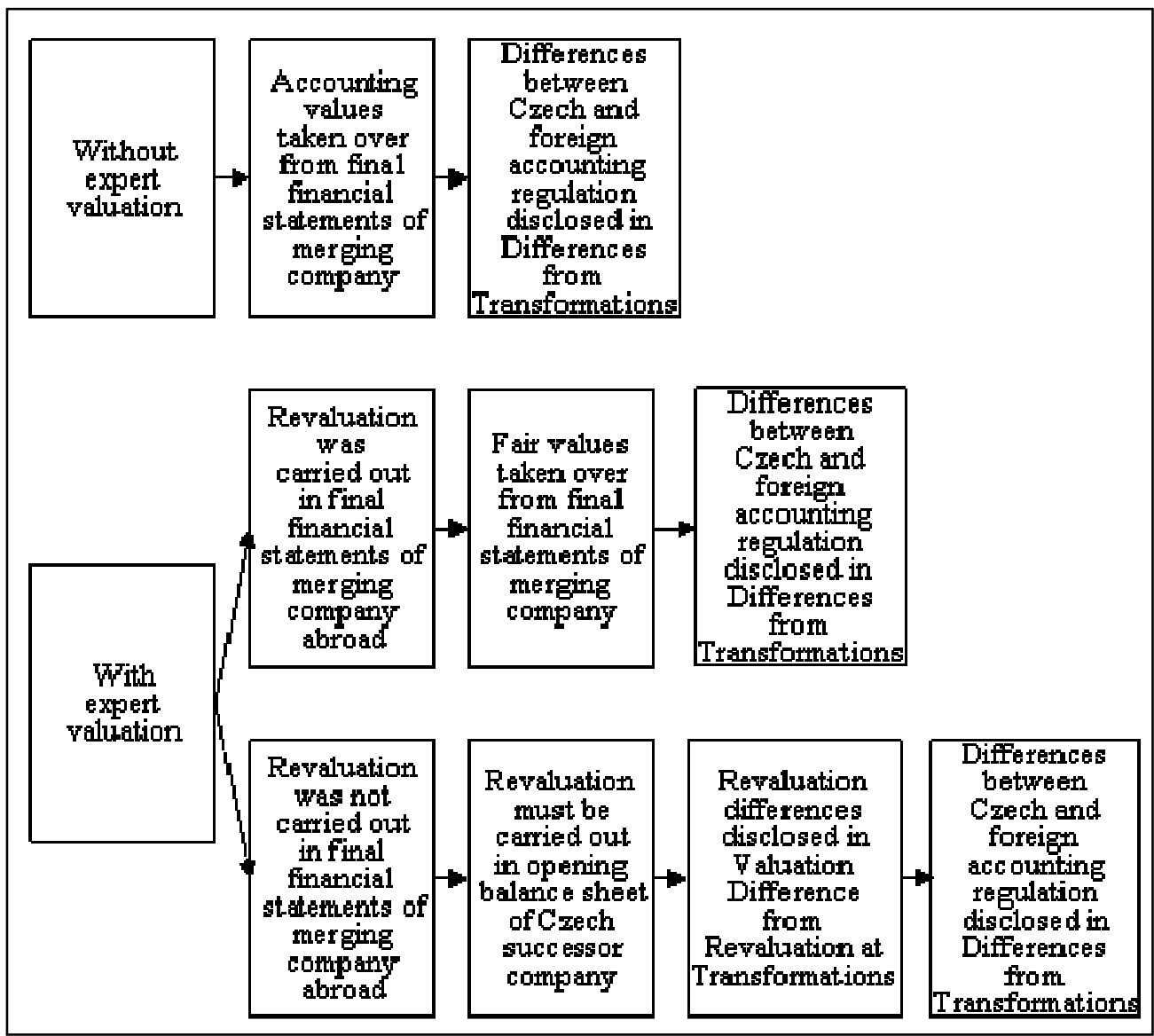

The aim of the item of equity Valuation Difference from Revaluation at Transformations is to record revaluation of assets and liabilities at fair value according to Czech Accounting Standards. It is used in case the foreign merging company did not revalue assets and liabilities according to foreign accounting standards in the final financial statements for the purposes of the merger. Since the final financial statements of the foreign merging company do not record assets and liabilities at fair value, the Czech successor company has to disclose the revaluation required by the BTA in the opening balance sheet prepared as of the decisive day and involve all differences in equity. 
The Valuation Difference from Revaluation at Transformations therefore is composed of all valuation differences between the accounting values of assets and liabilities disclosed in the final financial statements and fair values of assets and liabilities determined by the expert, which are disclosed in the opening balance sheet.

This part of equity can be used to increase the registered capital of the successor company based on the decision of shareholders embodied in the merger project approved by general meetings.

The successor company should keep accounting records of the transactions undertaken in the opening balance sheet. In fact, these records should be retained in the form of internal actuarial documents, which would document the step-up.

The Difference from Transformations is a newly introduced item of equity. It may include any differences recorded in the successor company that arise from dissimilar content definition of assets, liabilities and equity according to Czech and foreign legal regulation of accounting. This item shall be disclosed in the opening balance sheet of the successor company.

For the purposes of Czech accounting, the opening balance sheet followed by notes to the opening balance sheet will be the first accounting statement. The notes must follow up the cross-border merger project, which must in addition to general terms include also information on valuation of the assets and liabilities which are transferred to the successor company. This section of the project describes either the method of assets and liabilities fair value determination or procedures used to take over accounting values of the merging companies' assets and liabilities as well as transfers that were undertaken in equity of the successor company.

\section{Accounting Issues in Cross-border Mergers out of the Czech Republic}

As it has already been mentioned in this article, two possibilities may occur at a cross-border merger out of the Czech Republic. The Czech merging company can be dissolved and all its assets and liabilities can be transferred abroad. The foreign successor company will hence not conduct business activities in the Czech Republic. 
Czech Accounting Standards state that in this case the Czech merging company opens accounting books and keeps accounts on a separate basis from the decisive day. If the business activity of this company is terminated by the day when the merger is registered in the Commercial Register, the Czech merging company should close its accounting books as of this day. Additionally, the accounting books should be adjusted from the standard bookkeeping of an independent Czech accounting unit to the bookkeeping of an organisational component of a foreign company, which has no intention to continue doing business in the Czech Republic.

The second situation that may happen in a cross-border merger out of the Czech Republic concerns the foundation of a permanent establishment of the foreign successor company that will continue doing business in the Czech Republic. This situation and its timeline can be depicted in the following table.

Tab. 2: Merger step plan

\begin{tabular}{|c|c|c|c|}
\hline Date & Step & Accounting duty & Responsibility \\
\hline $31 / 12 / 2008$ & $\begin{array}{l}\text { Day preceding the } \\
\text { decisive day }\end{array}$ & $\begin{array}{l}\text { Final financial } \\
\text { statements, income } \\
\text { tax return }\end{array}$ & $\begin{array}{l}\text { Merging } \\
\text { company in the } \\
\text { CZE }\end{array}$ \\
\hline \multirow[t]{2}{*}{$01 / 01 / 2009$} & $\begin{array}{l}\text { Decisive day of } \\
\text { merger }\end{array}$ & $\begin{array}{l}\text { Opening balance } \\
\text { sheet of the foreign } \\
\text { successor company }\end{array}$ & $\begin{array}{l}\text { Foreign } \\
\text { successor } \\
\text { company }\end{array}$ \\
\hline & $\begin{array}{l}\text { Legal entity exists } \\
\text { in the CZE }\end{array}$ & $\begin{array}{l}\text { Separate } \\
\text { bookkeeping } \\
\text { pursuant to } \\
\text { Accounting Act }\end{array}$ & $\begin{array}{l}\text { Legal entity in } \\
\text { the CZE }\end{array}$ \\
\hline \multirow[t]{2}{*}{$31 / 08 / 2009$} & $\begin{array}{l}\text { Merger registration } \\
\text { in foreign } \\
\text { Commercial } \\
\text { Register; domestic } \\
\text { Commercial } \\
\text { Register noticed }\end{array}$ & \multirow{2}{*}{$\begin{array}{l}\text { Adjustment of } \\
\text { domestic accounts } \\
\text { based on the } \\
\text { decision of the } \\
\text { foreign successor } \\
\text { company - internal } \\
\text { decision on } \\
\text { accounting entries }\end{array}$} & \multirow[t]{2}{*}{$\begin{array}{l}\text { Foreign } \\
\text { successor } \\
\text { company }\end{array}$} \\
\hline & $\begin{array}{l}\text { De-registration of } \\
\text { legal entity in CZE } \\
\text { - its legal } \\
\text { dissolution }\end{array}$ & & \\
\hline
\end{tabular}




\begin{tabular}{|c|l|l|l|}
\hline Date & \multicolumn{1}{|c|}{ Step } & Accounting duty & Responsibility \\
\hline $01 / 09 / 2009$ & $\begin{array}{l}\text { Registration of } \\
\text { organisational } \\
\text { component of } \\
\text { foreign successor } \\
\text { company }\end{array}$ & $\begin{array}{l}\text { Bookkeeping of } \\
\text { organisational } \\
\text { component }\end{array}$ & $\begin{array}{l}\text { Organisational } \\
\text { component } \\
\text { (foreign } \\
\text { successor } \\
\text { company) }\end{array}$ \\
\hline
\end{tabular}

The internal decision of the foreign successor company - the founder of the organisational component in the Czech Republic should include many points that will influence its bookkeeping. The main issues are listed below.

- Organisational components as a rule do not have equity.

- Foreign founders supply organisational components with material or financial aid such as advance payments or contributions, which are settled with founders on an intercompany basis. These payments are generally disclosed as long-term liabilities.

- Organisational components may generate profit/loss from their activities. These resources belong to the founder and are not paid out in the Czech Republic according to the Commercial Code. Profit/loss should be settled against the liability towards the founder, which will decide upon the pay-out.

- Organisational components have to calculate the tax base and the tax duty in the Czech Republic based on agreements with local Tax Authorities. The paid tax is included in tax returns of the foreign founder in compliance with respective double tax treaties.

\section{Corporate Income Tax}

\subsection{Basic regulation}

Bookkeeping conducted pursuant to the Czech Accounting Standards is a starting point for corporate income tax base determination. Moreover, the concept of the decisive day, which is legally fictional and serves only for accounting purposes, has been implemented into the Income Tax Act from accounting regulation. As a result, transactions of the merging companies realised after the decisive day are included in the tax base of the successor company provided the merger is successfully accomplished.

The Czech Republic amended the Act No. 586/1992 Coll., Income Tax Act (Portal Gov, 1992), regarding the accession to the EU and 
implemented the Directive No. 90/434/EEC of 23 July 1990 on the common system of taxation applicable to mergers, divisions, transfers of assets and exchanges of shares concerning companies of different member states (Eur-Lex, 1990).

By means of this amendment, legal regulation of cross-border mergers penetrated into the Czech Income Tax Act. This tax regulation was not widely applicable, for practical realisation of cross-border mergers was limited to cross-border mergers to the European Company regulated by the Council Regulation No. 2157/2001 of 8 October 2001 on the Statue for a European Company (Eur-Lex, 2001) and the Czech Act No. 627/2004 Coll. on the European Company (Portal Gov, 2004). Further changes were introduced by the BTA or, strictly speaking, by related regulation that came into force together.

Although cross-border mergers are pursuant to the BTA possible for varying legal forms of companies, tax advantages are accorded only to a defined range of entities. In the Czech Republic, tax advantageous treatment is conferred if:

- The merging and successor companies are Czech tax payers and have the legal form of either a joint stock company or a limited liability company,

- The merging company is a tax resident of another EU member state and the successor company is a Czech tax payer and has the legal form of either a joint stock company or a limited liability company provided the assets and liabilities that were transferred from the merging companies to the successor company are not a part of a permanent establishment outside the Czech Republic,

- The merging company is a Czech tax payer and has the legal form of either a joint stock company or a limited liability company, the successor company is a tax resident of another EU member state and the assets and liabilities that were transferred from the merging companies to the successor company are a part of a permanent establishment in the Czech Republic.

In other words, tax advantages are not granted if a Czech successor company undertakes a cross-border merger with a merging foreign company and the assets and liabilities of this merging company remain abroad as a part of a permanent establishment of the Czech successor company. These cases may be rather frequent when the assets of merging 
companies cannot be physically moved to the Czech Republic such as real estate or businesses.

\subsection{Tax valuation of assets acquired in mergers}

Basic tax treatment of acquired assets and liabilities from abroad is stated in the Czech Income Tax Act. This law stipulates that any conversions of values of assets and liabilities acquired in mergers or demergers by Czech tax residents from foreign tax residents into CZK should be made using exchange rates of the Czech National Bank valid as of the decisive day unless these Czech tax residents have a permanent establishment in the Czech Republic. Any revaluation that may result from expert valuations of the assets and liabilities under legal regulations of the particular state for the purposes of mergers or de-mergers cannot be taken into account and thus must be excluded from the converted tax acquisition costs.

The same exchange rates should be used to convert the values of applied tax depreciation, tax adjustments, tax losses, tax provisions, tax deductible items or other tax applicable allowances under respective foreign legal regulations. The converted tax acquisition costs shall be used for all consecutive tax purposes, e.g. for valuation of stock and nondepreciable assets.

\subsection{Tax depreciation}

A Czech successor company is entitled to continue in tax depreciation of tangible and intangible assets from the converted tax acquisition costs of assets that were acquired in a cross-border merger from a foreign merging company and that were never a part of a permanent establishment in the Czech Republic. The original acquisition costs (i.e. before conversion into CZK) of these assets formed the tax depreciation base or were subject to similar tax allowances in the merging company's domicile. The Czech successor company should further:

- classify all acquired tangible assets into a relevant depreciation group according to the appendix of the Income Tax Act and linearly depreciate them by a rate for further years of depreciation stated in the Income Tax Act, 
- depreciate all acquired intangible assets for the remaining number of months stated in the Income Tax Act.

Tax depreciation can be applied in the Czech Republic up to the total amount that is determined by the difference between the converted tax acquisition costs and depreciation or similar tax allowances that were already applied in an EU member state in compliance with valid local legal regulations.

\subsection{Take-over of tax losses incurred abroad}

The Income Tax Act allows Czech successor companies to take over tax losses that were incurred by foreign merging companies and that have not been used yet.

The first precondition that must be met is that the assets and liabilities acquired in the merger which are related to the actual loss incurrence and which were located abroad will be moved to the Czech Republic as a result of the cross-border merger.

However, only those tax losses that were never utilised abroad (in any way) can be taken over by the successor company. Tax losses that were already applied as tax allowances or items otherwise decreasing the tax base in periods after the tax loss had been incurred or that were compensated against taxable profits realised by companies in the same consolidating group in such EU member states that allow group taxation (e.g. Austria) have to be excluded.

Furthermore, tax losses must be adjusted to the amount that would be achieved by a Czech tax payer benefiting from all tax instruments of the Czech Income Tax Act. It is therefore obvious that tax losses which were incurred abroad due to less strict thin capitalisation rules cannot be taken over and then utilised in the Czech Republic since such tax losses would not meet Czech think capitalisation rules. Other limiting conditions may be imposed on tax adjustments creation, tax deductibility of losses from sales of certain assets, etc.

Further to that, the tax base determination in the Czech Republic is concluded from bookkeeping conducted according to Czech Accounting Standards. In spite of the fact that the foreign merging company will almost certainly have double-entry bookkeeping, it should be checked 
that there are no material differences in accounting methods. In particular, such differences may stem from different stock valuation, activation of certain costs in assets acquisition prices, principles and methods of accruals and deferrals of expenses and revenues, etc.

It can be concluded that the adjustment of foreign tax losses to Czech conditions stipulated by Czech legislation may be sometimes excessively costly.

\section{Conclusion}

The new legal regulation facilitating cross-border mergers of common capital companies is prepared in accordance with the pattern of the EU in order not to obstruct these transactions or impede the freedom of movement of capital within the EU. On the contrary, it is still an open issue whether or not the supporting accounting and tax legislation will not be the obstacle that will henceforth hamper any upcoming mass crossborder mergers. At this point, tax advantages could be at least described as problematic or even unattainable. Therefore, it is not easy to predict in advance how the private sector will react to the newly implemented features; whether we will consequently enjoy many successful crossborder mergers or whether they will rest only in the appropriate sections of the relevant laws. In the Czech Republic, this process is undertaken via special accounts in equity. In some cases, the Czech successor company is allowed to record the transferred assets and liabilities at their accounting values (historical prices).

\section{References}

[1] Eur-Lex (1990): Council Directive 90/434/EEC of 23 July 1990 on the Common System of Taxation Applicable to Mergers, Divisions, Transfers of Assets and Exchanges of Shares Concerning Companies of Different Member States. [on-line] Luxembourg, Official Journal of the European Union, L225, 20 ${ }^{\text {th }}$ August, 1990, [cit. 25 April, 2009], $<$ http://eur-lex.europa.eu/LexUriServ/LexUriServ.do?uri=CELEX:31 990L0434:en:HTML>. 
[2] Eur-Lex (2001): Council Regulation No. 2157/2001 of 8 October 2001 on the Statue for a European Company. [on-line], Luxembourg, Official Journal of the European Union, L294, $10^{\text {th }}$ November, 2001, [cit. 26 ${ }^{\text {th }}$ April, 2009],

$<$ http://eur-lex.europa.eu/LexUriServ/LexUriServ.do?uri=CELEX:32 001R2157:EN:HTML>.

[3] Eur-Lex (2005a): Directive 2005/56/EC of the European Parliament and of the Council of 26 October 2005 on Cross-border Mergers of Limited Liability Companies. [on-line], Luxembourg, Official Journal of the European Union, L310, 25 ${ }^{\text {th }}$ November, 2005, [cit. 25 ${ }^{\text {th }}$ April, 2009], $<$ http://eur-lex.europa.eu/LexUriServ/LexUriServ.do?uri=CELEX:32 005L0056:EN:HTML>.

[4] Eur-Lex (2005b): Judgment of the Court (Grand Chamber) of 13 December 2005. SEVIC Systems AG. Reference for a Preliminary Ruling: Landgericht Koblenz. - Germany. Freedom of Establishment - Articles 43 EC and 48 EC - Cross-border Mergers - Refusal of Registration in the National Commercial Register - Compatibility. Case C-411/03. [on-line], Luxembourg, European Court reports 2005 Page I-10805, [cit. 25 ${ }^{\text {th }}$ April, 2009],

$<$ http://eur-lex.europa.eu/LexUriServ/LexUriServ.do?uri=CELEX:62 003J0411:EN:HTML>.

[5] IASB (2007): International Financial Reporting Standards (IFRSs). London, International Accounting Standards Board, 2007.

[6] MFČR (2009): Český účetní standard č. 011 (Financial Bulletin, Czech Accounting Standards No. 011). [on-line], Praha, Finanční zpravodaj, c2009, [cit. 26 ${ }^{\text {th }}$ April, 2009],

<http://www.mfcr.cz/cps/rde/xchg/mfcr/xsl/financni_zpravodaj.html ? year $=2003>$.

[7] Portal Gov (1991): Zákon č. 563/1991 Sb. o účetnictví (Act No. 563/1991 Coll., on Accounting). [on-line], c1991, [cit. 26 ${ }^{\text {th }}$ April, 2009], <http://portal.gov.cz/wps/portal/_s.155/701?kam=zakon\&c=563/1991>.

[8] Portal Gov (1992): Zákon č. 586/1992 Sb. zákon o daních z př́jmů (Act No. 586/1992 Coll., Income Tax Act). [on-line], c1992, [cit. $26^{\text {th }}$ April, 2009], <http://portal.gov.cz/wps/portal/_s.155/701?kam=zakon\&c=586/1992>. 
[9] Portal Gov (2002): Vyhláška č. 500/2002 Sb. (Public Notice No. 500/2002 Col.). [on-line], c2002, [cit. 26 ${ }^{\text {th }}$ April, 2009], <http://portal.gov.cz/wps/portal/_s.155/701?kam=zakon\&c=500/2002>.

[10] Portal Gov (2004): Zákon č. 629/2004 Sb. o evropské společnosti (Act No. 629/2004 Coll., on the European Company). [on-line], c2004, [cit. 26 ${ }^{\text {th }}$ April, 2009], <https://portal.gov.cz/wps/portal/_s.155/696/_s.155/701?1=627/2004>.

[11] Portal Gov (2008a): Zákon č. 125/2008 Sb. o přeměnách obchodních společností a družstev (Act No. 125/2008 Coll. on Transformations of Businesses and Cooperatives). [on-line], c2008, [cit. 25 ${ }^{\text {th }}$ April, 2009],

<http://portal.gov.cz/wps/portal/_s.155/701/.cmd/ad/.c/313/.ce/10821 /.p/8411/_s.155/701?PC_8411_number1=125/2008\&PC_8411_l=12 5/2008\&PC_8411_ps=10\#10821>.

[12] Portal Gov (2008b): Zákon č. 126/2008 Sb. (Act No. 126/2008 Coll.). [on-line], c2008, [cit. 25 ${ }^{\text {th }}$ April, 2009], <http://portal.gov.cz/wps/portal/_s.155/702/.cmd/ad/.c/312/.ce/10822 /.p/8412/_s.155/702/_ps.1272/M?PC_8412_b=126/2008\&PC_8412_ $\mathrm{ps}=10>$.

[13] Roubíčková, J. (2008): Otazníky nad zahraniční pobočkou (Question Marks over Foreign Entities). Český finanční a účetní časopis, 2008, vol. 4, no. 4, pp. 89-96.

[14] Skálová, J. - Čouková, P. (2008): Účetní a daňové dopady transakcí $v$ kapitálové společnosti (Accounting and Tax Impacts of Transactions in Business Companies). Praha, ASPI, 2008. 


\title{
Accounting Interpretation of Cross-border Mergers in the Czech Republic Based on Czech Accounting Standards
}

\author{
Jana SKÁLOVÁ - Tomáš PODŠKUBKA
}

\begin{abstract}
The paper deals with cross-border mergers that may be performed either out of or into the Czech Republic and focuses on the accounting and tax aspects of these transactions. Attention was also paid to the most important legal requirements imposed on merger projects and the net assets valuations. The Directive 2005/56/EC brought in new possibilities of business transformations across the EU member states' borders. Income tax advantages that may be gained in cross-border mergers were implemented by virtue of the Directive 90/434/EEC. It may be difficult to meet stringent requirements that are conditional upon enjoyment of the neutral tax treatment.
\end{abstract}

Key words: Cross-border Mergers; Czech Republic; Decisive Day; Merger Project; Opening Balance Sheet; Valuation Report.

JEL classification: G34, M41, H25. 